ЛЮДСЬКИЙ ПОТЕНЦАЛ ЯК НЕОБХІДНА УМОВА ПОДАЛЬШОГО
СТАНОВЛЕННЯ ОБ'ЄДНАНИХ ТЕРИТОРІАЛЬНИХ ГРОМАД В УКРАЇНІ

\title{
HUMAN POTENTIAL AS A NECESSARY CONDITION FOR FURTHER FORMATION OF UNITED TERRITORIAL COMMUNITIES IN UKRAINE
}

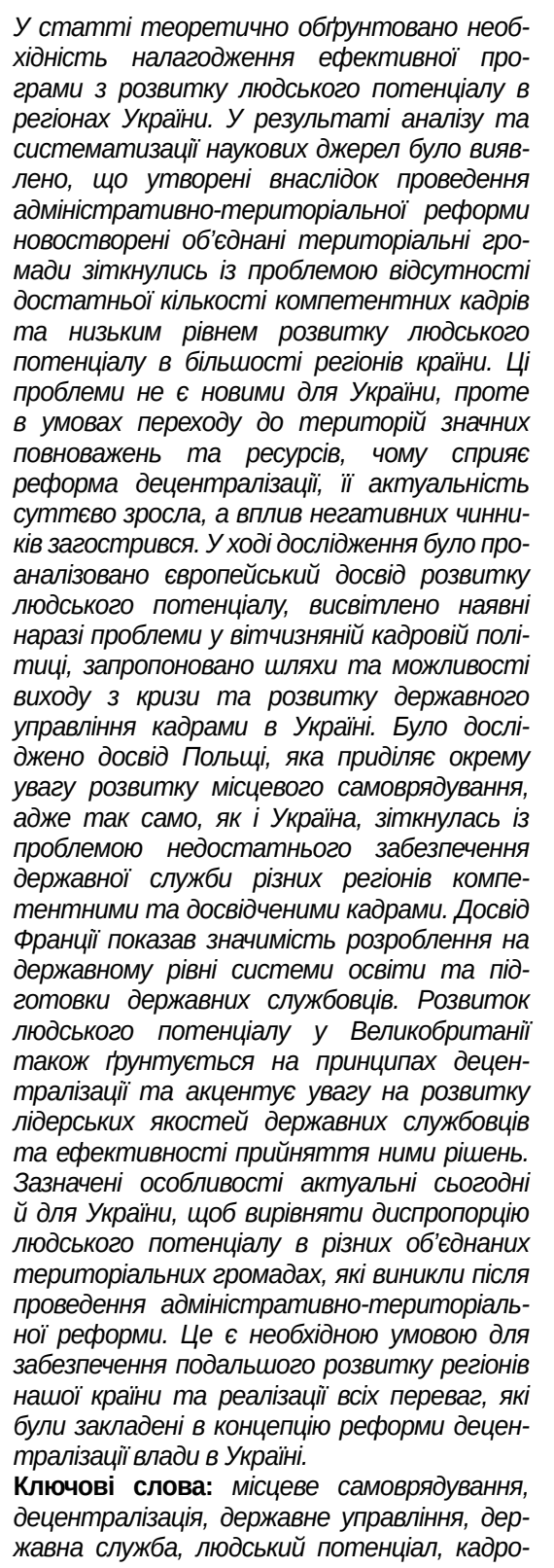
вий потенціал, концепт, концептуалізація досвіду, Україна, регіон, система, реформа, трансформація.

The article theoretically substantiates the need to establish an effective program for human development in the regions of Ukraine. As a result of analysis and systematization of scientific sources, it was found that the newly created united territorial communities formed as a result of administrative-territorial reform faced the problem of lack of sufficient competent staff and low level of human development in most regions of the country. These problems are not new for Ukraine, however, in the conditions of transition to the territories of significant powers and resources, which is facilitated by the decentralization reform, its urgency has increased significantly, and the impact of negative factors has intensified. The study analyzed the European experience of human development, highlights the current problems in domestic personnel policy, suggested ways and opportunities to overcome the crisis and the development of public personnel management in Ukraine. The experience of Poland, which pays special attention to the development of local self-government, was studied, because, like Ukraine, it faced the problem of insufficient provision of civil service in different regions with competent and experienced staff. The experience of France has shown the importance of developing a system of education and training of civil servants at the state level. Human development in the UK is also based on the principles of decentralization and focuses on the development of leadership qualities of civil servants and the effectiveness of their decision-making. These features are relevant today for Ukraine to balance the disproportion of human potential in the various united territorial communities that emerged after the administrative-territorial reform. This is a necessary condition for ensuring the further development of the regions of our country and the realization of all the benefits that were laid down in the concept of decentralization reform in Ukraine.

Key words: local self-government, decentralization, public administration, public service, human potential, personnel potential, Ukraine, region, system, reform, transformation.

\section{Гребоножко Є.П.}

д. фрілососрії з держ. упр., управління

Київський національний університет імені Тараса Шевченка
Постановка проблеми у загальному вигляді. Постійна та системна робота з формування та розвитку людського потенціалу $€$ запорукою ефективного функціонування та стабільної роботи державних органів. Це твердження $€$ справедливим як для столиці, так і для найвіддаленіших та найменших населених пунктів України. Проте якщо для великих міст питання кадрового забезпечення та людського потенціалу не $є$ критичним, то для новостворених об'єднаних територіальних громад по всій країні - це справжня криза. Відчувається гостра нестача людей, які би володіли відповідними компетенціями та знаннями. Саме тому питання розвитку людського потенціалу особливо актуалізується в контексті проведеної адміністративно-територіальної реформи.

Аналіз останніх досліджень і публікацій. Проблему людського потенціалу було розкрито в працях Г. Беккера, Е. Брукінга, В. Гейця, О. Грішнової, Г. Гузенка, Б. Данилишина, С. Клімова, В. Куценка, 
Е. Лібанової та ін. Питанню кадрової політики в системі державного управління приділяли увагу у своїх наукових статтях А. Замараєв, С. Дубенко, Д. Красівський, І. Лопушинський, В. Лук'яненко, Г. Мамчур, Т. Мотренко, Д. Неліпа, І. Пресняков, К. Проскурякова, О. Оболенський, В. Олуйко, І. Радіонова, Н. Римашевська, Н. Томчук, Н. Шаповалова, А. Чухно, В. Щетинін.

Виділення невирішених раніше частин загальної проблеми. Реформа децентралізації влади в Україні спрямована на розвиток територій шляхом передачі на місця значної кількості владних повноважень та ресурсів для їх реалізації. Адміністративнотериторіальна складова частина реформи вже реалізована. Вона створила в країні нові об'єднані територіальні громади (далі - ОТГ), які й мають перебрати на себе всі можливості, які пропонує децентралізація. Проте відкритим залишилось питання кадрової кризи, яка вже давно характерна для окремих регіонів нашої держави. Не всі території мають однаково розвинений людський потенціал, не для всіх характерна велика концентрація компетентних людей, деякі населені пункти страждають від урбанізації, внутрішньої міграції, демографічної кризи тощо. Саме це створює необхідність для розроблення і впровадження загальнонаціональної програми розвитку людського потенціалу. Це є просто необхідним для того, щоб ефективно завершити впровадження реформи децентралізації та забезпечити подальший розвиток усіх без виключення ОТГ.

Мета статті - розроблення рекомендацій щодо впровадження програми розвитку людського потенціалу в Україні як необхідної умови подальшого розвитку новостворених об'єднаних територіальних громад.

Перш ніж визначити сучасний стан розвитку людського потенціалу в державній службі України, варто визначити, що ми маємо на увазі під терміном «людський потенціал». Варто зазначити, що загальноприйняте та вичерпне визначення в сучасному науковому дискурсі відсутнє. Енциклопедичний словник 3 державного управління трактує його як «довготривалий запас знань, навичок і компетенцій індивіда, які отримуються переважно шляхом навчання та трудового досвіду і можуть бути використаними у процесі життєдіяльності» [3, с. 372].

Загалом, виокремлюють два аспекти розуміння людського потенціалу:

- ресурсний - сукупність певних ресурсів, що використовуються для отримання результатів визначеної мети;
- наявність певних обставин, які підвищують рівень віддачі від присутніх для суб'єкта $[4$, c. 57$]$.

С. Селіванов зазначає, що «розуміння людського потенціалу включає такі властивості людини, як інтереси та потреби, рівень здоров'я, рівень життя, мотивація діяльності, загальні та професійні знання, кваліфікація, способи поведінки ставлення до трудової діяльності, ініціативність та підприємливість» [7, с. 48-53].

Після завершення адміністративно-територіальної реформи та остаточного поділу території України на окремі об'єднані територіальні громади особливо гостро постала проблема кадрової кризи та недостатнього розвитку людського потенціалу в регіонах. На місця перейшла велика кількість повноважень, коштів і ресурсів, якими отримала змогу розпоряджатись громада. Проте людей, які б мали для цього відповідний рівень знань та компетенцій, наразі недостатньо. Особливо відчутними ці проблеми проявились у контексті діджиталізації та пандемії, коли необхідність налагоджувати дистанційне надання послуг та реагувати на непередбачувані ситуації продемонстрували слабкий кадровий потенціал регіонів.

Ускладнюється ситуація ще й рядом викликів, які для України вже можна назвати характерними, а саме це: диспропорція розвитку та розподілу людського потенціалу в межах країни, зростання кількості депресивних регіонів, недооціненість людського потенціалу в порівнянні з іншими ресурсами, недостатня мотивація до саморозвитку, послаблення ролі соціальних ліфтів, відсутність методологічної основи управління формуванням та розвитком людського потенціалу, невизначеність загального спрямування суспільного розвитку [2].

Проаналізувавши зазначені проблеми та сформувавши стратегію їх вирішення, ми зможемо, нарешті, забезпечити ефективний управлінський вплив на формування людського потенціалу і створення достатньої бази людського ресурсу та забезпечити підвищення стандартів життя громадян.

Показовим для нас може виступати досвід держав Європейського Союзу, насамперед державної служби Польщі. Корпус державної служби Польщі функціонує на засадах компетентності, професіоналізму, справедливості, неупередженості та сумлінного виконання обов'язків [9]. Набору та функціонуванню кадрів цієї служби приділено багато уваги в політичній системі країни. Проте проведення адміністративно-територіальної реформи в 
Польщі все ж позначилось на роботі державної служби, яка зіткнулася з нестачею кадрів, що поставило під удар реалізацію стратегію регіонального розвитку країни [1, с. 319]. Зміни адміністративно-територіального устрою призвели до поглиблення розриву в рівні соціально-економічного розвитку регіонів країни. Ситуація була подібною до тієї, яку ми маємо сьогодні в Україні.

3 досвіду Польщі ми можемо сформувати декілька аспектів, які сприяють розв'язанню зазначених вище проблем. Необхідно:

- віднайти правильний баланс національних та регіональних стратегій розвитку (польський уряд сформував стратегію інноваційного розвитку для 5-ти найбільш депресивних регіонів);

- сформувати відповідну законодавчу базу, яка сприятиме розвитку людського потенціалу;

- провести серію громадських обговорень та налагодити ефективність освітньої політики.

Також польський уряд доволі активно сприяв розвитку місцевого самоврядування, яке для регіонів дуже часто є справжньою «кузнею кадрів». Саме ефективна система місцевого самоврядування дозволяє формувати в населених пунктах резерв компетентних та вмотивованих людей, яких надалі можна залучати до державної служби. Надання місцевому самоврядуванню реальних повноважень здійснювалось згідно 3 «Конституційним законом про відносини між законодавчою та виконавчою владами республіки Польщі та про місцеве самоврядування» від 17 жовтня 1992 р., де місцеве самоврядування визначено основною формою організації громадського життя на місцях (Ст. 70) [5, с. 249-250].

Для Франції реформа в галузі державної служби вилилась у концепцію «професійної освіти протягом усього життя». Реформа розпочалась у 2007 році та тривала до 2012 року. Головним вектором розвитку людського потенціалу у Франції стали децентралізація та комп'ютеризація державної служби. У пакті «Публічна служба 2012» було зафіксовано курс на зменшення кількості державних службовців та паралельне підвищення їх ефективності за рахунок безперервної професійної освіти та самоосвіти [6].

Децентралізованою є і система державної служби Великобританії. Вона також орієнтована на підвищення кваліфікації та професійного розвитку кадрів. Державна стратегія орієнтована на підвищення якості послуг та розвиток навичок і лідерських якостей службовців, що допомагає їм більш ефективно функціонувати в неординарних та кризових ситуаціях. Сьогоднішня пандемія, конфлікт на Сході України та активний вплив децентралізації показують, що подібний підхід є вкрай ефективним та необхідним і для України. Також у Великобританії вироблено власну «систему оцінки компетентності», яка визначає вимоги до державних службовців і їх відповідність цим вимогам [8, с. 41].

Всі згадані вище заходи націлені на забезпечення розвитку людського потенціалу та створення компетентного кадрового резерву по всій території країні. Для України з її величезною кількістю новостворених ОТГ це $є$ позитивним досвідом, який варто використати в процесі вдосконалення системи державної служби.

Висновки. Люди, які працюють на державній службі, - це обличчя держави. Вони повинні викликати довіру в суспільства, репрезентувати надійність та ефективність, адже ці люди $\epsilon$ важливим елементом ефективного функціонування держави. Саме тому питання розвитку людського потенціалу, особливо для країни, де відбулись зміни адміністративно-територіального устрою, є вкрай актуальним та нагальним. Децентралізація сучасної системи державного управління сьогодні особливо актуалізує проблему кадрового забезпечення об'єднаних територіальних громад. Проте ця проблема може бути вирішена під час розроблення відповідних науково-методологічних засад формування і функціонування людського потенціалу громад на основі досвіду країн Європейського Союзу. Особливої уваги заслуговує принцип пожиттєвої професійної освіти та самоосвіти державних службовців Франції, пристосування кадрів до роботи в мінливих і кризових ситуаціях, на чому акцентує увагу система Великобританії, розвиток місцевого самоврядування як основи людського потенціалу регіонів (у відповідності до досвіду Польщі).

\section{ЛITEPATУРA:}

1. Адамович С.В. Адміністративно-територіальна реформа в Польщі: використання досвіду в українських реаліях. Українознавчі студії. 2007/2008. № 8/9. С. 316-322.

2. Гребоножко Є.П. Концептуалізація європейського досвіду формування людського потенціалу в системі державного управління: можливості для України (на прикладах Польщі, Німеччини та «вестмінстерської» моделі Великобританії). Теорія та практика державного управління. 2018. Вип. 2. C. 242-249.

3. Енциклопедичний словник 3 державного управління / уклад. : Ю.П. Сурмін та ін. Київ : НАДУ, 2010. $820 \mathrm{c}$ 


\section{ПУБЛІЧНЕ УПРАВЛІННЯ І АДМІНІСТРУВАННЯ В УКРАЇНІ}

4. Козарезенко Л.В. Державне регулювання розвитку людського потенціалу в контексті політики підвищення якості життя населення. Економіка розвитку. 2014. № 1 (69). С. 55-63.

5. Конституції нових держав Європи та Азії / за ред. С.В. Головатого. Київ : Укр. Правн. Фундація, 1996. $250 \mathrm{c}$.

6. Ресрорма професійної освіти протягом всього життя (FPTLV) : введена Законом Франції 32007-148 від 02.02.2007 р. URL: http://www.pravo. vuzlib.net/book_z1181_page_73.html (дата звернення: 17.06.2021).
7. Селіванов С.В. Підходи до розуміння кадрового потенціалу в органах державної влади в Україні. Slovak international scientific journal (Bratislava, Slovakia). 2018. Part 2. № 14. C. 48-53.

8. Accreditation of Universities to Grand Degrees in Social Work (online) / General Social Care Council/ (ed. M. Wardle). London : General Social Care Council, 2002. 41 p.

9. The Civil Service system in Poland. Kancelaria Prezesa Rady Ministrów. URL: https://dsc.kprm. gov.pl/en/what-is-the-civil-service (дата звернення: 17.06.2021). 